\title{
Dobroczynność w Wilnie w latach reaktywowania polskiej samorządności (1919-1927)
}

\author{
Charity activities in Vilnius in the times of rebirth \\ of the Polish self-government (1919-1927) \\ Summary:
}

The article explores one of the difficult topics from the turbulent time of the birth of the II Polish Republic - migrations of refugees who were running away from various conflicts that engulfed the region in the beginning of 1920s. The author sets out to assess the sanitary and social conditions in the city until the year 1927, based on documentation from the Lithuanian State Modern Archive (Lietvas centrinis valstybes archywas).

Słowa kluczowe: Wilno, opieka charytatywna, opieka społeczna, zdrowotna, repatriacja

Keywords: Vilnius, charity, social care, health care, repatriation

\section{Wprowadzenie}

Wilno - miasto Kresów wschodnich i centralnej Europy - z początkiem lat 20. XX w. stało się teatrem działań wojennych: rosyjskich, niemieckich, sowieckich oraz okupacji tych państw. Z mieszkańcami dzieliło los przemieszczających się przez ten obszar obcych wojsk ${ }^{2}$. Poszukiwali tu także schronienia uciekinierzy ze Wschodu, głównie

1 O wcześniejszym okresie: lat 1905-1907 i pomocy ubogim w Wilnie pisał Roman Jurkowski, Wileńskie instytucje i towarzystwa dobroczynne w latach 1905-1907, $w$ świetle doniesień „Kuriera Litewskiego” $i$ „Dziennika Wileńskiego”, cz. 1, „Przegląd Wschodnioeuropejski” 2016, nr 7/1, s. 29-44.

${ }^{2}$ J. Kłos, Wilno, Przewodnik krajoznawczy, Wilno 1937, s. 35-41. 
Polacy. Przy czym trudna jest do oszacowania liczba przybywających do miasta ${ }^{3}$. W sytuacji istniejącej migracji, w tym ludności cywilnej, zmierzającej w kierunku zachodnich obszarów ziem polskich, Wilno było miejscem tzw. pobytu „etapowego”. Problemem stawało się zapewnienie repatriantom ze Wschodu pomocy, podstawowych środków do życia. Ponadto - prowadzenia akcji zapobiegawczej, walki z pojawiającymi się epidemiami i z wszelką patologią społeczną.

Przedmiotem analizy jest ocena sytuacji sanitarnej Wilna oraz poznanie możliwości i form zaspokajania potrzeb społecznych, częściowo i zdrowotnych ludności w mieście do $1927 \mathrm{r}^{4}$ Materiały dotyczące tej problematyki są dostępne w litewskim archiwum akt nowych, tj.: Lietvas centrinis valstybes archywas w Wilnie, na Antokolu. Wzbogacają je informacje prasowe, ale i dane zaczerpnięte z tamtejszych kalendarzy, roczników statystycznych czy też ksiąg adresowych.

\section{Po czasach zaborów, od 1919 r.}

W kwietniu 1919 r., po wyzwoleniu z pewnych „pozostałości” po zmieniających się zaborcach, polski magistrat ${ }^{5}$ przejął nadzór nad

${ }^{3}$ Według Andrzeja Gawryszewskiego w roku 1920 liczbę ludności w całej Litwie Środkowej obliczano na 0,5 mln. W samym Wilnie, według danych z roku 1919, znajdować się miało 129 tys. ludności, gdy w 1927 r. - 170 tys. Tymczasem w roku 1931 - 195 tys., w tym 65,94\% Polaków, 27,99\% Żydów, 3,7\% Rosjan, 0,89\% Białorusinów, 0,81\% Litwinów i 0,3\% innych narodowości. Rocznik statystyczny Rzeczypospolitej Polskiej, 1927, R. 5, Warszawa 1927, s. 22. Lietvas centrinis valstybes archywas w Wilnie (dalej LCVA) LCVA, sygn. 64/19/70, k. 612. A. Gawryszewski, Ludność Polski w XX wieku, Warszawa 2005, http://rcin.org.pl/Content/2425/WA51_13508_r2005-nr5_Monografie.pdf; Encyklopedia PWN, hasło Wilno, https:/encyklopedia.pwn.pl/haslo/Wilno;3996406.html. Według zaś R. Jurkowskiego w Wilnie w roku 1909 żyło 174 tys. mieszkańców, co może wskazywać aż na 50-tysięczny spadek ludności do 1919 r. spowodowany działaniami wojennymi. Por. R. Jurkowski, dz. cyt., s. 35. Warto dodać, że w 1917 r. w Wilnie panował głód, ludność miasta została znacznie uszczuplona. Ewakuowano wtedy urzędy, fabryki do Rosji, ale i przenoszono się z miasta na wieś, gdzie stosunkowo łatwiej było wtedy przeżyć. Księga adresowa miasta Wilna 1935, Wileński Kalendarz Informacyjny, R. XXX, Wilno 1935, s. 40-41.

${ }_{4} 1927$ r. był pewnym etapem w II RP - zakończenia porządkowania kwestii społecznych, rozpoczętych zasadniczo ustawą o opiece społecznej z 16.08.1923 r., uzupełnianą w następnych latach, m.in. w 1925 r. i wreszcie dwa lata później kilkoma rozporządzeniami. Ustalano kwestie związane z nadzorem i kontrolą tego pionu, kwalifikacjami pracowników, problemem żebractwa. Szerzej na ten temat pisze Agata Samsel, Rodziny potrzebujace wsparcia w II Rzeczypospolitej - jakość życia, realizacja podstawowych funkcji, opieka społeczna, „Wychowanie w Rodzinie” 2013, t. VII/1, s. 248-249.

5 Samorządy terytorialne poszczególnych miast sukcesywnie organizowano na ziemiach polskich od 1919 r. Powodem opóźnionego jednak w czasie procesu tworzenia 
istniejącymi w Wilnie instytucjami użyteczności publicznej i ich podopiecznymi. Personel placówek sanitarno-leczniczych i opiekuńczych z trudem jednak usiłował zapewnić minimum egzystencji zgłaszającym się po pomoc. Do instytucji tych należały m.in. zakłady dobroczynne utrzymywane przez różnorodne instytucje, stowarzyszenia prywatne, zakonne, organizacje wyznaniowe, ale i finansowane też prawdopodobnie jeszcze do marca 1919 r. np. przez rosyjski Prikaz Obszczestwiennego Prizronija czy Obczczestwo Dobrochotnej Kopiejki ${ }^{6}$. Niełatwe jest jednak ustalenie wysokości nakładów poniesionych przez te organy, zwłaszcza wobec zmieniającej się sytuacji: okupacyjnej władzy, sytemu jej sprawowania czy stanu trwających niepokojów związanych z wojną. Uważa się, że jedną z tych instytucji był zakład dla starców, utrzymywany przez Dobrochotną Kopiejkę. Mieścił się, jak odnotowano w polskiej dokumentacji magistratu, w murach św. michalskich (kościoła pod tym wezwaniem, u wylotu zaułka Świętomichalskiego i przy ul. Św. Anny) ${ }^{7}$. Zakład przez gromadzących się tu potrzebujących rozrósł się znacznie, dlatego kolejnych ubiegających się o wsparcie i zakwaterowanie lokowano już w pomieszczeniach pobonifraterskich ${ }^{8}$. Fakt umiejscowienia tam zakładu, ale i inicjatora jego założenia - jeszcze „rząd rosyjski” - potwierdza Juljusz Kłos. Co więcej, Kłos twierdzi, że decyzja o umieszczeniu tam dużej liczby bezdomnych nie była do końca wyważona, doszło bowiem w tym czasie i może za ich udziałem do zniszczenia oryginalnych i ,wielu ciekawych fragmentów budynku poklasztornego". Jednak poza tymi informacjami wiadomości o funkcjonowaniu zakładu są niezwykle skąpe, podobnie jak dotyczące liczby tam rozlokowanych.

polskiej samorządności w wielu przypadkach była sytuacja w kraju. Na ten fakt wpływała także konieczność porządkowania różnych uregulowań administracji państwowej pochodzących jeszcze z czasów zaborów. Ostatecznie sprawę tych uregulowań ustalił dekret Naczelnika Państwa z 4.02.1919 r. oraz m.in. rozporządzenie Komisarza Generalnego Ziem Wschodnich z 26.09.1919 r. o samorządzie gminnym. Od tego roku organem uchwałodawczym i kontrolnym w miastach stawała się rada miejska, wybierana na trzy lata, a wykonawczym - magistrat $\mathrm{z}$ burmistrzem, jego zastępcami i ławnikami oraz jego wydziałową administracją. R. Stawicki, Samorzad terytorialny w II Rzeczypospolitej. Zarys prawno-historyczny, Warszawa 2015, s. 9-10; J. Dziobek-Romański, Samorzad terytorialny w II Rzeczypospolitej w pierwszych latach po odzyskaniu niepodległości, [w:] Historia magistra vitae. Ksiegga jubileuszowa, Lublin 2007, s. 63-75.

${ }^{6}$ LCVA, sygn. 64/24/65 (brak pag).

7 J. Kłos, dz. cyt., s. 139.

${ }^{8}$ LCVA, sygn. 64/24/65 (brak pag.).

9 J. Kłos, dz. cyt., s. 142-143. 
W 1920 r. ponownie nastąpiło pogorszenie położenia Wilna, które latem zostało zajęte przez Armię Czerwoną ${ }^{10}$. Po wyjściu jej wojsk w pierwszych dniach maja 1920 r. i sowieckiej ,decyzji przekazania miasta Litwie" tutejsze władze nie zaniechały jednak starań o uporządkowanie sytuacji społeczno-zdrowotnej. Instytucje dobroczynne i sanitarno-lecznicze organizacyjnie podporządkowano wileńskiemu Wydziałowi Opieki Społecznej tutejszego magistratu. Wśród pozostających pod tym nadzorem znalazły się szpitale: św. Jakóba, Sawicz, żydowski, zakaźny oraz domy podrzutków, przytułki dla starców oraz „ochrony” dla dzieci. Podlegały one wszystkie, od roku 1919, zarządowi miasta, o czym już wspominano ${ }^{11}$. Łącznie na przełomie 1919/1920 r. wykazano funkcjonowanie 17 placówek opiekuńczych, w których wtedy, według wydziału, znajdowało pomoc 279 osób: dorosłych i dzieci. Prawdopodobnie nadal istnieć mogły także instytucje prowadzone przez różne towarzystwa charytatywne, wykazywane w pierwszej dekadzie XX w., działające na rzecz potrzebujących. Jednym z nich mogło być jeszcze Towarzystwo opieki nad biednymi z siedzibą przy ul. Trockiej $14^{12}$, którym do roku 1911 administrował jego twórca Józef Montwiłł ${ }^{13}$. W ramach towarzystwa prowadzono: szpitalik „Stowarzyszenia Sług św. Zyty”, przytułek, Dom sierot św. Wincentego i „Kroplę Mleka”14.

Ponadto w październiku 1920 r. prezes zarządu gminy żydowskiej wykazywał funkcjonowanie odrębnych instytucji opiekuńczo-leczniczych przewidzianych dla ludności żydowskiej ${ }^{15}$.

Stowarzyszenie ochrony zdrowia ludności izraelskiej, co prawda dopiero według danych z 24.04.1924 r., wykazywało istnienie na Pohulance, pod nr 18, i to od roku 1920, przytułku dla podrzutków,

${ }^{10}$ W. Kozyra, Polityka administracyjna władz polskich na Ziemiach Wschodnich Rzeczypospolitej polskiej w latach 1918-1926, „Annales Universitates Mariae Curie-Skłodowska” 2005, t. LIX, s. 422.

${ }^{11}$ LCVA, sygn. 64/19/22, k. 2.

12 Potwierdzeniem istnienia jeszcze $\mathrm{w}$ tym czasie tego miejsca była informacja o funkcjonowaniu w latach 30 . XX w. przy ul. Trockiej 14 (w tzw. murach pofranciszkańskich) kuchni ludowej. Księga adresowa miasta Wilna, Wileński Kalendarz informacyjny na rok 1933, s. 114.

13 Józef Montwiłł (1850-1911) - ziemianin, prawnik z wykształcenia, bankowiec, społecznik i filantrop wileński. N.R, Józef Montwiłł, „Tygodnik Wileński”, 13.02.1911, nr 26, s. 4; Fr.N., Józef Montwitt jako filantrop „Tygodnik Wileński”, s. 4-7. Instytucje te zostały uwzględnione $\mathrm{w}$ wykazie magistratu z roku 1919/1920, aczkolwiek nie pod dawną nazwą z $1911 \mathrm{r}$.

14 „Tygodnik Wileński”, dz. cyt., s. 4-7. Kalendarz ilustrowany „Kurjera Litewskiego" na rok 1909, s. 86-87.

${ }^{15}$ LCVA, sygn. 64/24/82 (brak pag.). 
Dobroczynność w Wilnie w latach reaktywowania polskiej samorządności...

Tabela 1. Wykaz wileńskich instytucji dobroczynnych (opiekuńczych) ${ }^{16}$, stan 1919/1920 r.

\begin{tabular}{|c|l|c|}
\hline Lp. & \multicolumn{1}{|c|}{ Nazwa zakładu* } & Liczba podopiecznych \\
\hline 1. & Ochrona „Caritas” & 29 \\
\hline 2. & „Wygnańców” z Petersburga & 13 \\
\hline 3. & Ochrona Reformowana & 13 \\
\hline 4. & Ochrona nr 4 & 6 \\
\hline 5. & Dom Opieki Matki Bożej & 4 \\
\hline 6. & Dom św. Kazimierza & 34 \\
\hline 7. & Pogotowie Ratunkowe & 7 \\
\hline 8. & Dom opieki nad Chorymi & 41 \\
\hline 9. & Żłobek Dzieciątka Jezus & 10 \\
\hline 10. & Ochr. (?) Ostrobramska & 14 \\
\hline 11. & Żłobek Miłosierdzia & 10 \\
\hline 12. & Ochr. Im. Wiwulskiego & 9 \\
\hline 13. & Pol. Ochrona Parafialna & 3 \\
\hline 14. & Schronisko dla bezdomnych & 44 \\
\hline 15. & Ochrona Serca Jezusowego & 20 \\
\hline 16. & Towarzystwo Opieki nad Dziećmi & 12 \\
\hline 17 & Polskie Towarzystwo Ofiar Wojny & 279 \\
\hline Łącznie & & \\
\hline
\end{tabular}

* Lokalizacja siedzib tych zakładów w tym czasie nie została ujawniona. Źródło: LCVA, sygn. 64/24/38, k. 7. W wykazie nie uwzględniono instytucji leczniczych.

Tabela 2. Instytucje dla ludności żydowskiej w 1920 r.

\begin{tabular}{|c|l|l|c|}
\hline Lp. & \multicolumn{1}{|c|}{ Nazwa instytucji } & \multicolumn{1}{|c|}{ Adres } & $\begin{array}{c}\text { Liczba } \\
\text { podopiecznych }\end{array}$ \\
\hline 1. & Ochrona Talmud Tora & Nowa 5 & ok. 300 \\
\hline 2. & Ochrona Achieser & Św. Anny 9 & 185 \\
\hline 3. & Ochrona G.Marks & Konarska (?) 51 & 70 \\
\hline 4. & „Dla sierot” & Ostrobramska 39 & 263 \\
\hline 5. & Dom Starców & Portowa 7 & 320 \\
\hline 6. & $\begin{array}{l}\text { Kolonia dla słabych } \\
\text { dzieci }\end{array}$ & Letnia 1 & 70 \\
\hline 7. & Szpital & Zwierzyniec, Wesoła 15 & 80 \\
\hline
\end{tabular}

Źródło: LCVA, sygn. 64/24/82 (brak pag.).

${ }^{16} \mathrm{~W}$ rozumieniu instytucji pomocowych dla ludności cywilnej, o charakterze głównie społecznym. 
kierowanych tam, jak zaznaczono, przez policję. Lokowano także $\mathrm{w}$ tym miejscu dzieci nieślubne oraz tzw. zaniedbane i sieroty. W tym czasie przebywało w przytułku ok. 30. dzieci. Grupa zgromadzonych dzieci miał się opiekować lekarz, pięć pielęgniarek i personel pomocniczy - kuchenny, a także mamki karmiące niemowlęta ${ }^{17}$.

Niemniej wydaje się, że stan liczbowy podopiecznych w niektórych, przytoczonych placówkach może nie w pełni obrazować panującą tam sytuację. Chociaż należy też pamiętać, że podawane przez pracowników dane o podopiecznych mogły mieć wpływ na uzyskanie wsparcia ze strony władz miasta. Usprawiedliwieniem pojawiającej się pewnej wątpliwości, a i powodem wrażenia np. o „zaniżaniu” niektórych danych, mogło być niebezpieczeństwo przebywających w Wilnie spowodowane działaniami. Wpływało ono na labilność, tymczasowość pobytu ludności w mieście, określanego mianem etapowego. W efekcie też często jej czasowe przebywanie w zakładach pomocy. Zasadniczym bowiem zamiarem przemieszczającej się przez miasto ludności, zwłaszcza wschodnich uciekinierów po utracie domostw na terenach zabranych, było poszukiwanie bezpiecznego i zapewne stałego już miejsca do życia. Warunki w mieście także mogły nie zachęcać do dłuższego pobytu. Stan wojny powodował, że koszty jej prowadzenia dominowały nad innymi dziedzinami gospodarki, nie sprzyjały normalizacji sytuacji i utrzymania się przez dłuższy czas $\mathrm{w}$ Wilnie. W celu sfinansowania wysiłku wojennego prowadzono politykę inflacyjną. Następowała reglamentacja surowców i żywności ${ }^{18}$. Miasto przez wycofujące się wojska zostało ograbione $\mathrm{z}$ wszelkich zapasów żywności, także ze środków transportu zapewniających dostawę towarów. Infrastruktura wielu obiektów, w tym leczniczych, została zniszczona. Brakowało środków opatrunkowych, podstawowych leków, bielizny. Pomimo tych trudności miejskie władze starały się sukcesywnie organizować opiekę, nowe placówki: do przyjmowania zagrożonych, zwalczenia różnych niebezpieczeństw, w tym epidemiologicznych. Urządzano łaźnie, np. przy Kalwaryjskiej 7, odwszalnie, domy izolacyjne, także placówki przeznaczone dla chorych zakaźnie. Odnotowano np. przy ul. Łukiskiej 7, wedle danych z 1921 r., izbę dezynfekcyjną ${ }^{19}$. Próbowano przeprowadzać szczepienia ochronne, jednak, jak donoszono, ludność bardzo niechętnie im się poddawała. Przytaczanym powodem miały być powikłania, co prawda o lekkim

${ }^{17}$ LCVA, sygn. 64/24/152, k. 82.

18 W. Musiał, Modernizacja Polski. Polityki rzadowe w latach 1918-2004, Toruń 2013, s. 263-264.

${ }^{19}$ LCVA, sygn. 64/19/20, k. 94 (dane z 20.02.1921 r.). 
przebiegu, ale dość uciążliwe, zważywszy na panujące wtedy warunki. Ponadto w przypadku płonicy (szkarlatyny) przeprowadzano je w dawkach trzykrotnych, a reakcja poszczepienna też mogła wtedy odstraszać. Ogółem w drugiej połowie lat 20. np. w przypadku płonicy pracownicy Sekcji Zdrowia ${ }^{20}$ przeprowadzili je tylko u 384 osób, a nie $\mathrm{u}$ wszystkich poddanych szczepieniom przebiegało bezobjawowo. Bowiem wśród zaszczepionych, co prawda tylko u pięciu z nich, zaobserwowano wystąpienie znamion choroby. Informacje te jednak pochodzą dopiero z końca roku 1926, gdyż do wcześniejszych, a dotyczących np. płonicy, nie udało się dotrzeć ${ }^{21}$. Wprawdzie próbowano dokonywać rejestracji zachorowań na choroby zakaźne, jednak zapewne nie wszystkie przypadki. Jak należy przypuszczać, dotyczyły one głównie osób już z zidentyfikowaną przez personel medyczny chorobą. Wydaje się zatem, że dane te nie są dostatecznie miarodajnie i nie ukazują wileńskiej rzeczywistości epidemiologicznej w tamtym czasie. Aczkolwiek w miarę rozwoju funkcjonowania służb sanitarnych stawały się one bardziej dokładne. Potwierdzają to sprawozdania służb sanitarnych, ale dopiero $\mathrm{z}$ drugiej połowy lat 20. i początków lat $30 . \mathrm{XX} \mathrm{w}^{22}$. Podejrzewać można, że działania zapobiegawcze stosownych instytucji do połowy lat 20. nie mogły być wystarczające i przeciwdziałać rozwojowi chorób, zwłaszcza zakaźnych.

Tabela 3. Dane dotyczące zachorowań w Wilnie na choroby zakaźne, czerwiec-październik 1919 r.

\begin{tabular}{|c|c|c|c|}
\hline Lp. & Rodzaj chorób & Liczba osób & Zmarli \\
\hline 1. & odra, róża* & 27 & brak danych \\
\hline 2. & czerwonka - cholera & 91 & 20 \\
\hline 3. & tyfus plamisty & 200 & 33 \\
\hline 4. & tyfus brzuszny & 26 & brak danych \\
\hline 5. & tyfus powrotny & 184 & 2 \\
\hline
\end{tabular}

* Dane dotyczące niektórych chorób przytoczono łącznie.

Źródło: LCVA, sygn. 6/24/8 k. 1-4; 6/24/6 k. 24-26 (brak danych dotyczących np. płonicy).

Warto zatem dodać, że dane zawarte w tabeli z pewnością nie dają pełnego obrazu zachorowań. Jedynym wytłumaczeniem mogła być

${ }^{20}$ Por. przyp. 30.

${ }^{21}$ LCVA, sygn. 64/19/57, k. 231, 233.

${ }_{22}$ Por. np. Sprawozdanie z działalności urządzeń sanitarnych i leczniczych 1 I-1 IV 1925 LCVA, sygn. 64/19/38, k.16. Sprawozdanie z działalności organizacji sanitarnych 1 X-31 XII 1927, LCVA, sygn. 64/19/70, k. 607, 613. 
sytuacja miasta i brak możliwości dotarcia do wszystkich chorujących, o czym już wzmiankowano, ponadto wspominana kilkakrotnie labilność mieszkańców, przemieszczanie się ludności. Aczkolwiek i w tym trudnym czasie istniał nadzór epidemiologiczny sprawowany przez lekarzy sanitarnych ${ }^{23}$. Liczba lekarzy sanitarnych dostosowana była do cyrkułów miejskich ${ }^{24}$. W 1919 r. istniało 9 cyrkułów i tyluż lekarzy sanitarnych nadzorujących sytuację higieniczno-zdrowotną ludności w mieście.

Tabela 4. Wykaz lekarzy sanitarnych 1919-1923 r.

\begin{tabular}{|l|l|}
\hline \multicolumn{1}{|c|}{ Nr porządkowy cyrkułu } & Imię i nazwisko lekarza sanitarnego \\
\hline I cyrkuł & dr Samuel Poczler* \\
\hline II cyrkuł & dr Michał Brodzki \\
\hline III cyrkuł & dr Marjan Kewlecz \\
\hline IV cyrkuł & dr Wacław Bądzyński \\
\hline V cyrkuł & dr Henryk Wrześniowski \\
\hline VI cyrkuł & dr Stanisław Dokalski \\
\hline VII cyrkuł & dr Witold Legiejko \\
\hline VIII cyrkuł & dr Adolf Narkiewicz** \\
\hline IX cyrkuł & dr Daniel Jarncowski \\
\hline
\end{tabular}

* Zmarł 19.11.1927 r. LCVA, sygn. 64/19/34, k. 3.

** Po zmniejszeniu liczby lekarzy sanitarnych 24.02 .1924 r. przeniesiony został do pogotowia ratunkowego, tamże, s. 4.

Źródło: LCVA, sygn. 64/19/34, k. 3.

Lekarze sanitarni zobowiązani byli do kontroli sanitarnej, w ramach przydzielonych im rejonów, znajdujących się tam obiektów, działalności instytucji zapobiegawczych i zatrudnionego personelu. Podstawowym zaś ich obowiązkiem było zwalczanie ognisk zakażenia i rozwoju epidemii w mieście. Sytuacja $\mathrm{w}$ tym zakresie była jednak niepokojąca. Poważnym i stałym problemem był stan sanitarny placówek, jak meldowano: „prawie niezmieniony od kilku lat”. Obraz jednej z placówek, z roku 1919, przedstawił (?) Gutowski, delegowany do przeprowadzenia kontroli przytułku przy ul. Św. Anny 7. W notatce pokontrolnej napisał: „(...) brudy w łóżkach i pod łóżkami, u kobiet pod nogami i pod głową sterta

${ }^{23}$ Stanowisko lekarza sanitarnego powstało w roku 1911, uprzednio (od 1899 r.) w Wilnie całość zadań związanych z nadzorem nad stanem zdrowotności, higieny sprawowała Miejska Rada Sanitarna. LCVA, sygn. 64/19/37, k. 106. s. 32.

${ }^{24}$ Rejon administracyjny miasta i policyjnego nadzoru. Por. R. Jurkowski, dz. cyt., 
łachmanów: ścierek, zmywaków cuchnących, przed wejściem gęsty dym: kobiety dogotowywały w piecach. Jedna ze staruszek skarżyła się na brak absolutnej opieki ze strony pielęgniarek, elementarny brak dozoru (...) dochodzi do bójek"25. W innym z raportów, z końca października 1919, prawdopodobnie ze wspomnianego już przytułku przy św. Anny, skierowanym do kierownika Wydziału Dobroczynności, donoszono i o takiej sytuacji: „W przytułku żebracy, chroniący swoje łachmany, załatwiają się na podłodze (...)"26. Istniały ogromne problemy aprowizacyjne. Z początkiem $1920 \mathrm{r}$. Wydział Opieki Społecznej zmuszony został prosić: „(...) telegraficznie Departament Opieki Społecznej przy Ministerstwie Spraw Wewnętrznych aby przyznać Wydziałowi zapomogi (ale i - dop. autora) niezwłocznie wysłać pod adres wydziału tanich produktów w postaci żyta, pszennej mąki i tłuszczów" ${ }^{27}$. Próbowano też samodzielnie dokonywać zakupów produktów spożywczych, sprowadzając je nawet $\mathrm{z}$ odległych terenów. Zachowała się w tej sprawie notatka jeszcze z listopada 1919 r., skierowana do naczelnika Okręgu Wileńskiego, w której Wydział Dobroczynności zwracał się o wydanie przepustki „(...) Stanisławowi Piotrowskiemu do Warszawy i z powrotem dla eskortowania słoniny zakupionej przez Wydział Opieki Społecznej dla miejskich zakładów dobroczynnych" 28 .

W czasie złej sytuacji aprowizacyjnej padały też pod adresem personelu instytucji dobroczynnych oskarżenia o nieuczciwość, ale i o malwersacje. W jednym z meldunków policyjnych, także jeszcze z sierpnia 1919 r., przytoczono następujący przypadek „(..) $20 \mathrm{bm}$. (...) Stanisława Głębocka, (...) jako chora zgłosiła się do szpitala (schroniska - dop. autora) dla nieuleczalnych, przy zaułku Rossa 3 zaś przełożona szpitala Bronisława Pepinska ją wypędziła za to, że nie chciała kraść różnych rzeczy: blach, piecyków”. W dalszej części meldunku padło kolejne oskarżenie pod adresem przełożonej - o zawyżanie stawek żywieniowych: wypisywanie stanu 50 podopiecznych przy faktycznej obecności ${ }^{29}$. Dokonując rozeznania sytuacji, stwierdzono: „Pepinska unika kontroli (...) na 12 łóżek chorej ani jednej, poszukując w ogrodzie odnaleziono 7 kobiet, mężczyzn - 5. Razem 12. Są jeszcze osoby dochodzące na obiady - 22. Pensjonariusze to głównie

${ }^{25}$ Do Pana kierownika Wydziału Opieki. Protokół z kontroli przytułku 25 X 1919 r. LCVA, sygn. 64/24/48 (brak pag.).

${ }^{26}$ Tamże.

${ }^{27}$ LCVA, sygn. 64/24/82 (brak pag.).

${ }^{28}$ LCVA, sygn. 64/24/38, k. 298.

${ }^{29}$ Tamże, k. 108, 263. 
paralitycy, chorzy psychicznie, na artretyzm, zołzy, chroniczne zapalenie gruźlicze" 30 .

W połowie 1920 r. stan 118 łóżek w samym mieście powiększono do $550^{31}$, kontynuując $\mathrm{w}$ tym zakresie starania w następnych latach. Istotną rolę $\mathrm{w}$ walce $\mathrm{z}$ chorobami zakaźnymi miał pełnić personel szpitala zakaźnego (epidemicznego) ${ }^{32}$ na Zwierzyńcu (ul. Grodzka 10), którego lekarzem naczelnym był dr Władysław Szwengruben. W okresie 1.03.1919-1.03.1920 przyjęto do szpitala 4979 chorych $^{33}$. Szpital rozmieszczony był w kilku budynkach, od 11.03.1921 r. funkcjonował pod nadzorem Nadzwyczajnego Naczelnego Komisarjatu do walki z epidemiami $^{34}$.

\section{Po zmianach organizacyjnych i utrwaleniu przynależności państwowej miasta}

Od roku 1921 starano się, mimo trudności, przeprowadzić remonty zniszczonych wojną szpitali, obliczono, że koszty z tym związane wyniosą $3 \mathrm{mln}$ mkp, aczkolwiek przewidywano przeznaczenie tej sumy głównie dla trzech szpitali: św. Jakóba, żydowskiego i Sawicz - dla chorych skórno-wenerycznych ${ }^{35}$. Pomoc medyczną, ale już w całym województwie, udzielano w 33 szpitalach o łącznej liczbie 1980 łóżek. W lecznictwie zatrudnionych było przeszło 300 lekarzy, przy czym w pierwszym kwartale 1927 r. obliczano ich stan na 390 osób ${ }^{36}$. Funkcję naczelnego lekarza w mieście sprawował dr Michał Minkiewicz, odpowiedzialny za całość opieki zdrowotnej. Stanowisko to prawdopodobnie pełnił dr Minkiewicz od lutego $1921 \mathrm{r} \cdot{ }^{37}$ Lekarzowi naczelnemu podlegała Sekcja Zdrowia magistratu, w której pracowało dwóch refe-

\footnotetext{
${ }^{30}$ Tamże, k. 264. Dokument podpisał lekarz sanitarny V cyrkułu 1.09.1919 r.

${ }^{31}$ LCVA, sygn. 64/19/22, k. 2.

${ }^{32}$ Szpital epidemiczny założono około połowy roku 1917 na terenie byłej fabryki zamków. LCVA, sygn. 64/19/14, k. 3-8.

${ }^{33}$ LCVA, sygn. 64/24/2, k. 71; LCVA, sygn. 64/19/348, k. 6.

${ }^{34}$ LCVA, sygn. 64/19/20, k. 93.

${ }^{35}$ LCVA, sygn. 64/19/313, k. 67.

${ }^{36}$ Rocznik statystyczny Rzeczypospolitej Polskiej, R. 5, 1927, s. 476, 480.

37 Dr Michał Minkiewicz (1858-1943) - członek Konwentu Polonii był współtwórcą Wileńskiego Koła Filistrów. Redagował „Lekarza Wileńskiego”. Do rejestru służby miejskiej Minkiewicz został wpisany 7 lutego $1921 \mathrm{r}$. W rubryce przy stanie swojej rodziny podał: córkę Marję i syna Jana. Konwent Polonia - Archiwum Korporacyjne, http://www.archiwumkorporacyjne.pl/index.php/muzeum-korporacyjne/wilno/ [dostęp: 6.11.2016]. Wykaz personelu Sekcji Zdrowia na dzień 21 I 1923. LCVA, sygn. 64/19/34, k. 1-2. Funkcja lekarza naczelnego miała zostać skasowana w roku 1934, a wszystkie agendy zdrowia i opieki, odtąd połączone, znajdować się miały pod kierunkiem naczelnika Wydziału Zdrowia i Opieki Społecznej. LCVA, sygn. 64/19/157, k. 190.
} 
rentów, kontroler oraz cztery biuralistki kancelarii ${ }^{38}$. Pracą sekcji od 1924 r. kierował dr Michał Abinkiewicz ${ }^{39}$. Sekcja Zdrowia dysponować miała przy ul. Trockiej (nr?) składem sanitarnym dla placówek leczniczo-opiekuńczych z zapasami pościeli, bielizny, ubrań, tzw. rezerwą, w praktyce, jak się okazywało, z niezbyt bogatą liczbą produktów tam zgromadzonych ${ }^{40}$.

Przy ul. Dominikańskiej 2 funkcjonowało pogotowie ratunkowe, w którym zatrudniono trzech lekarzy: dr. Kazimierza Kodzia (jako kierownika), dr. Eugeniusza Herlego, dr Tatjanę Paszkową oraz jednego felczera i czterech sanitariuszy ${ }^{41}$. Po $1920 \mathrm{r}$. utworzono komitet obyczajowy z działem ds. prostytucji. W skład personelu placówki leczniczo-zapobiegawczej wchodziło m.in. pięciu lekarzy, w tym lekarz naczelny, 6 felczerów, 12 pielęgniarek. Chorych wenerycznie leczono bezpłatnie. Ta grupa chorób należała bowiem do jednej $\mathrm{z}$ najczęściej występujących w mieście. Dodać należy, że zarówno kiła, jak i zapewne rzeżączka za czasów bolszewickich nie podlegały nie tylko obowiązkowi rejestracji, ale także leczeniu. W 1921 r. odnotowano już 1355 leczących się stacjonarnie w placówce i 41116 pacjentów, którym udzielono doraźnej porady medycznej w zakresie chorób wenerycznych $^{42}$. W myśl ustawy z 16 sierpnia $1923 \mathrm{r}$. istniejący przy magistracie Wydział Dobroczynności zobowiązany został, korzystając z subsydiów miejskich, do utrzymywania instytucji dobroczynnych „przynależnych do gminy Wilno" ${ }^{43}$. Niemniej obowiązek roztoczenia opieki dotyczył osób (matek, dzieci) przebywających w obrębie gminy co najmniej przez rok ${ }^{44}$. Tymczasem, jak odnotowano $\mathrm{w}$ dokumentacji miasta, nadal: „Wilno spełnia posługi zdrowotno-sanitarne dla znacznego obszaru rodzącej się Polski”, co wiązało się ze wspomnianym już czasowym pobytem ludności w Wilnie wędrującej do innych części ziem polskich ${ }^{45}$. W związku z tą sytuacją członkowie Sekcji Zdrowia już 20 marca 1920 r. przypominali: „(...) do szpitali kierować zamiej-

\footnotetext{
${ }^{38}$ LCVA, sygn. 64/19/34, k. 2.

${ }^{39}$ Tamże, k. 22.

${ }^{40}$ LCVA, sygn. 64/19/20, k. 90.

${ }^{41}$ Tamże. LCVA, sygn. 64/19/34, k. 4.

${ }^{42}$ LCVA, sygn. 64/19/20, k. 91.

${ }^{43}$ LCVA, sygn. 64/24/155 (brak pag.).

${ }^{44}$ Tamże.

${ }^{45}$ Tamże. Szacuje się, że do roku 1924 do Polski powróciło nawet do $3 \mathrm{mln}$ osób, głównie z Rosji. Łącznie na kształtujących się polskich pograniczach utworzono 170 placówek przejściowych i tzw. etapów. P. Majer, Struktura, zadania i prawne podstawy działalności aparatu państwowego II RP do spraw reparacji, reemigracji i emigracji, „Studia Prawnoustrojowe” 2015, nr 27, s. 168.
} 
scowych, którzy zgodzą się płacić i złożą $350 \mathrm{mkp}$ lub potwierdzi to gmina, w przypadku dłuższego pobytu ponownie pobrać awans, wyjątek: zagrożenie życia lub choroba zakaźna"46.

Na przełomie roku 1923/1924 nastąpiła jednak redukcja cyrkułów, a także liczba zatrudnionych lekarzy sanitarnych ${ }^{47}$. Z uwagi na występujące ciągle jeszcze zachorowania na choroby zakaźne, społeczne, problem migracji ludności i stan sanitarny miasta decyzja ta budzić może wątpliwości. Powodem mogły być względy finansowe, co potwierdza opisywana poniżej sytuacja wielu placówek opiekuńczo-leczniczych miasta. Aczkolwiek sądzi się też, że od roku 1923 na ziemiach polskich miał nastąpić spadek liczby zachorowań na niektóre choroby zakaźne, w tym cholerę, ospę (?) ${ }^{48}$ (niewykazywaną w podanym powyżej wykazie), co mogło, jak się wydaje, wpłynąć też na czynione oszczędności w zakresie liczby zatrudnionych lekarzy w tej dziedzinie.

Stan niepewności, a zwłaszcza ,przelewanie się” przez miasto różnorodnej rzeszy ludzi, przedłużający się do połowy lat $20 . \mathrm{XX} \mathrm{w}^{49}$, pogłębił jednak złą sytuację sanitarno-zdrowotną. Rozszerzały się epidemie niektórych chorób, zwłaszcza duru brzusznego, powrotnego $^{50} \mathrm{i}$ wspomnianych chorób wenerycznych. W całym województwie północno-wschodnim, w tym i w Wilnie, nadal panowała ,influensa”, zwana hiszpanką, szerząca się z ogromnym natężeniem na ziemiach polskich zwłaszcza w okresie 1918-192051. Jej natężenie obserwowano nadal w następnych latach, szczególnie w miesiącach zimowych i je-

${ }^{46}$ LCVA, sygn. 64/24/2, k. 60.

${ }^{47}$ LCVA, sygn. 64/19/37, k. 106.

${ }^{48}$ A. Felchner, Rodzina w II Rzeczypospolitej-jej główne zagrożenia ze strony chorób, „Medycyna Nowożytna. Studia nad Kulturą Medyczną” 2019, t. 25, z. 1, s. 111.

${ }^{49}$ Pod pozorem buntu oddziały Lucjana Żeligowskiego 9.10 .1920 r. zajęły miasto, w efekcie dalszych posunięć politycznych nastąpiło włączenie do Polski Litwy Środkowej z Wilnem, które stało się stolicą woj. wileńskiego, jednak utworzonego dopiero w 1926 r. na mocy ustawy z 22.12.1925 r. R. Sawicki, Samorzad terytorialny w II Rzeczypospolitej. Zarys prawno-historyczny, Warszawa 2015, s. 11. Jednak obszar województwa kształtowany był od 1920 r. do 14 marca 1923 r., Księga adresowa miasta Wilna 1935, s. 43.

50 Aczkolwiek w latach 1922-1923 nie odnotowano w mieście duru osutkowego, pewne nasilenie jego występowania miało miejsce w niektórych gminach, m.in. solecznikowskiej. Do urzędu Delegatury Rządu. LCVA, sygn. 55/8/1167 (brak pag.).

51 A. Jezierski, C. Leszczyńska, Historia gospodarcza Polski, Warszawa 2003, s. 226; J. Wnęk, Pandemia grypy hiszpanki (1918-1919) w świetle polskiej prasy, „Archiwum Historii i Filozofii Medycyny” 2014, t. 77, s. 16-23; R. Kuzak, Grypa hiszpanka w Polsce 1918-1920. Liczba ofiar i prawdziwy obraz epidemii https://wielkahistoria.pl/grypahiszpanka-w-polsce-1918-1920-liczba-ofiar-i-prawdziwy-obraz-epidemii/ [dostęp: 26.03.2020]. 
siennych. I tak, np.: w styczniu 1926 r. zapadło na nią w całym województwie 1648 osób, w listopadzie - 1635, w grudniu tego roku odnotowano 2488 przypadków. Łącznie w całym roku 1926 zaraziło się grypą 15305 osób, a łącznie zmarło 59 osób $^{52}$. Z powodu złego odżywiania rozwijał się także niebezpieczny wtedy szkorbut. Wedle danych ze wspomnianego $1926 \mathrm{r}$. odnotowano w samym Wilnie: 652 przypadki duru brzusznego, 660 duru plamistego, 1600 płonicy (szkarlatyny), 267 błonicy (dyfterytu), 1275 odry ${ }^{53}$. Jednak dużą śmiertelność przysparzała gruźlica - w 1926 r. zmarły 402 osoby. Apelowano do władz rejonowych, ale także centralnych o pomoc, w tym przyznanie zapomóg, pożyczki na utrzymanie przebywających w mieście, działalność instytucji leczniczo-sanitarnych. Listy w tych sprawach, redagowane przez władze miejskie, w tym lekarza naczelnego, kierowano do delegata rządu RP już 26.06.1921 $\mathrm{r}^{54}$ Ich treść formułowana była często $\mathrm{w}$ alarmistycznym tonie. Podawano sumy określające potrzeby ludności, podopiecznych tych instytucji, np. 400 tys. mkp (dla placówek leczniczych) i 16 tys. (dla instytucji dobroczynnych). Przy czym traktowano te kwoty jako pewną rekompensatę na pokrycie deficytu w okresie 1.051919-1.05.1920 r. za poniesione wydatki. Apelowano też o stałe zapomogi do czasu uspokojenia sytuacji. Sugerowano przyznawać je w formie miesięcznych subwencji dla konkretnych placówek, np. szpitala św. Łazarza czy św. Jakóba, zaznaczając, że 31\%, a nawet $50 \%$ przebywających tam chorych było zamiejscowych ${ }^{55}$. Przytaczano przy tym realne koszty utrzymania jednego chorego, wynoszące na początku lat 20. u św. Jakóba 21,50 mkp, a w szpitalu Sawicz - 28 mkp. Podawano jednocześnie obowiązujące wtedy w Wilnie ceny rynkowe za konkretne towary, np. za płótno na pościel dochodzące nawet do $400 \mathrm{mkp}^{56}$. Przypomnieć wypada, że do połowy 1921 r. obowiązywało zaopatrzenie kartkowe. Dotyczyło ono głównie mieszkańców miast, tj. 15\% ludności ziem polskich. Obejmowało ono zakup tą drogą towarów pierwszej potrzeby, takich jak m.in.: chleb, cukier, mydło ${ }^{57}$. Potrzeby zgłaszane przez pracowników placówek do magistratu i odpowiednich jego komórek dotyczyły zaś różnych produktów i spraw do załatwienia. Nierzadko wynikały z potrzeb „dnia codziennego”,

52 D. Kieziewicz, Zdrowotność i lecznictwo $w$ pótnocno-wschodnich województwach Rzeczypospolitej Polskiej, „Nowiny społeczno-lekarskie” 1929, nr 1, s. 17.

53 W całym województwie 7089 osób. Tamże.

${ }^{54}$ LCVA, sygn. 64/19/22, k. 9.

55 Tamże, k. 6.

56 Tamże, k. 6-9 (początek lat 20. XX w.).

57 A. Jezierski, C. Leszczyńska, dz. cyt., s. 264. 
np. konieczności zainstalowania pieca, dostarczenia łóżek, sienników ${ }^{58}$ czy dostarczenia trumien, a nawet oczyszczenia ustępów. Przykładowe zamówienia na wyżej wymienione usługi czy sprzęty zgłoszone zostały m.in. przez personel przytułku dla starców przy Placu Napoleona $6^{59}$. Bywało jednak, że nie $\mathrm{w}$ pełni realizowano zamówienia, a nawet znacznie je ograniczano ${ }^{60}$. Meldowano też do władz, kontrolując zarazem wyposażenie placówek, o deficytowych towarach, jak np. bieliźnie szpitalnej, której stan w wielu przypadkach można było określić jako niezwykle ubogi czy nawet katastrofalny. I tak, np. w przytułku przy Kościele bonifraterskim dysponowano, przy większej liczbie potrzebujących, łącznie 30 sztukami bielizny, w tym 5 prześcieradłami, 3 poszewkami czy 4 ścierkami. W tym względzie panowało $\mathrm{w}$ mieście „prawdziwe ubóstwo”. Rodziny tam zmarłych zgłaszały się nawet po „resztki” pozostawionego po nich dobytku, nierzadko niezwykle nędznego, $\mathrm{w}$ tym i bielizny ${ }^{61}$. Podobnie było $\mathrm{z}$ aprowizacją. $\mathrm{W}$ domu starców dla „izraelitów” przy Portowej 17, odnotowanym w wykazie Wydziału Dobroczynności magistratu, przebywało 300 starców „obu płci”, dla których od zarządu pozyskano „(...) 70-80 pudów mąki i krupy”, ale ilość ta okazała się niewystarczająca. Próby zakupu produktów u „prywatnych kupców” w mieście przekroczyły możliwości kierownictwa wielu placówek, jak stwierdzono, było „za drogo”. Tymczasem, jak zaznaczono, „starcy cierpią głód”62. Początkowo przy niektórych, jak np. wspomnianym już przytułku przy ul. Pl. Napoleona, udawało się utrzymać nawet bydło i to w liczbie dwóch krów i kóz. Przynajmniej figurowało ono jeszcze $\mathrm{w}$ wykazach pierwszych miesięcy (?) 1920 r. Ale jak się okazuje, „żywe zapasy żywności” nie wystarczyły na długo. Być może zostały zarekwirowane, o czym jednak nie informują źródła. Bowiem jeszcze w tym roku kobiety ulokowane w tym miejscu zwróciły się pisemnie „do burmistrza miasta Wilna”, jak zaznaczyły, w formie „najpokorniejszej prośby”, pisząc „(...) o doli kobiet w oczekiwaniu na śmierć (...) otrzymano tylko mąkę na 2 tygodnie, w takiej ilości jak za bolszewików, (tj. - dop. autora) półtora funta na osobę i więcej nic (...) z tej mąki (sporządzały - dop. autora) biały żurek, krochmalik”. Żaląc się dalej, pisały: „Bolszewicy dawali

${ }^{58} \mathrm{Z}$ prośbą o dostarczenie łóżek i bielizny pościelowej zwrócił się jesienią $1919 \mathrm{r}$. personel Domu Opieki Matki Bożej przy Senatorskiej 29. LCVA, sygn. 64/24/38, k. 289.

${ }^{59}$ LCVA, sygn. 64/24/47, k. 1.

${ }^{60}$ LCVA, sygn. 64/24/38, k. 291.

${ }^{61}$ LCVA, sygn. 64/24/47, k. 1.

${ }^{62}$ LCVA, sygn. 64/24/38, k. 281. 
chleb, teraz brak (od 3 tygodni). Męki głodowe”63. Prosiły „władzę” o kartofle, śledzie, uznane wtedy za najprostsze, a pożywne produkty żywnościowe, tłumacząc się: „my nie mamy groszy przy duszy”64. Opis ten potwierdzał tragiczne warunki panujące $\mathrm{w}$ placówkach, o których jeszcze wtedy w podobnym tonie informował Główny Urząd Żywnościowy: kierownik Wydziału Dobroczynności oraz prezes kuratorium opieki nad biednymi. Wskazywali oni przy okazji na przyczyny krytycznie ocenianej sytuacji: „Żydzi i Litwini, Moskale otrzymywali stałe zapomogi: z Ameryki, od Taryby Litewskiej z Kowna i od Niemców, (a) polskie instytucje «na wymieraniu» (...) stan ten wykorzystują wrogowie" ${ }^{65}$. Dodać trzeba, że pobyt pensjonariuszy w przytułkach, zwłaszcza z obszaru gminy, był bezpłatny. Informowała o tym Sekcja Zdrowia magistratu już 20 marca $1920 \mathrm{r}^{66}$

W placówkach opiekuńczych nadal wybuchały niepokoje. Ich sprawcami byli często prowadzący zakład czy właściciele lokalów. Oskarżano ich nierzadko o „grubiańskie zachowanie”, prowokowanie bijatyk, utrudnianie pobytu ${ }^{67}$. Przykładowo, w przytułku dla starców $\mathrm{nr} 1$ przeprowadzono dochodzenie w sprawie pobicia pensjonariusza Wacława Markiewicza i głuchoniemego „bez nazwiska” przez Annę Lach, pielęgniarkę, która biła po twarzy, rzuciła cegłą. Przyczyną była ,jakoby kradzież kury”68. Podobne sytuacje i skargi na „,bijatyki i przekleństwa”, nierzadko podpisywane przez pensjonariuszy, zdarzały się i w innych miejscach ${ }^{69}$.

Mimo trudnej sytuacji poszukiwano różnych środków zaradczych w celu poprawy sytuacji: zaopatrzenia, aktualizowano normy żywnościowe. W niektórych placówkach powoływano grupy złożone z pensjonariuszy, nadzorujące przyjmowane produkty żywnościowe, realizowane jadłospisy, a i pełniących dyżury w kuchni ${ }^{70}$. Starano się, aby osoby przewidziane do tych zadań wybierano np. na okres sześciu miesięcy na ogólnym zgromadzeniu pensjonariuszy ${ }^{71}$. Otwarto też giełdę

${ }^{63}$ Tamże, k. 69 .

${ }^{64}$ Tamże, k. 70.

${ }_{65}$ Tamże, k. 85.

${ }^{66}$ LCVA, sygn.64/24/2, k. 62.

67 Do Wydziału Opieki..., LCVA, sygn. 64/24/153 (brak pag.).

${ }_{68}^{6}$ Protokół z 10 II 1923 r., LCVA, sygn. 64/24/132 (brak pag.).

${ }^{69}$ Skarga z 1925 r. na Niedzwieckich skierowana do Wydziału Społecznego i Opieki. LCVA, sygn. 64/24/153 (brak pag.).

${ }^{70}$ Komitety gospodarcze w przytułkach dla starców, LCVA, sygn. 64/24/108 (brak pag.).

${ }^{71}$ Tamże. 
pracy dla bezrobotnych ${ }^{72}$. Przeprowadzano kontrolę placówek, poszukując nadużyć, wadliwego gospodarowania. Niektóre z tych działań, np. w zakresie poprawy aprowizacji, czasem okazywały się skuteczne. Dokonując np. 24.04.1922 r. rewizji stanu przytułku przy Pl. Napoleona 6, w którym zarządzającym był wtedy Aleksander Rutkowski, stwierdzono: „(...) wyżywienie wystarczające ale brak czystości, wietrzenia sal, składy łachów pod łóżkami. Sale potrzebują bielenia"73. $\mathrm{Na}$ ul. Rossa 2 „w murach poklasztornych” funkcjonował kolejny przytułek, w którym rozlokowano też część oddziałów wojskowych. Z uwagi na szczupłość powierzchni pomieszczeń zwrócono się do dowództwa o opuszczenie przez nich obiektu. Powodem tej decyzji były jednak choroby zakaźne, szerzące się wśród przebywających tam dzieci. $\mathrm{Z}$ epidemii wymieniano choroby oczu (?), zapewne jaglicę, ale i koklusz. Panowała przy tym duża śmiertelność, na przestrzeni tylko tygodnia zmarło sześcioro dzieci. Odnotowano wydanie w okresie siedmiu dni sześciu trumienek. Epidemie wymusiły zatrudnienie do opieki nad chorymi ośmiu, jak zaznaczono, „czasowych pielęgniarek".

Wobec oznak wszechobecnej biedy, nie tylko u podopiecznych, ale także w samych placówkach, zalecano nadal „nie przyjmowanie (do tych instytucji - dop. autora) osób obcych”, spoza Wilna ${ }^{74}$. Stan miasta oceniała także Komisja Sanitarna szefa sanitarnego Dowództwa Grupy wojsk Litwy Środkowej. Po przeprowadzonej wizji miasta jeszcze 23.05.1921 r. określono go jako „zatrważający”. Polecono oczyścić teren „z brudów” odpadków, ekskrementów (...) jeszcze przed ciepłą porą roku". Jak zaznaczono, miano to jednak uczynić głównie środkami mieszkańców i zarządu miejskiego, z pomocą władz wojskowych i państwa. Zlecono w tym celu dostarczenie aut do wywózki śmieci, ale i uporządkowanie części miasta zajętego przez wojsko. Ponadto zarządzono skoszarować wojsko, aby nie rozwlekano epidemii różnych chorób, stykając się z ludnością miasta. Do wykonania tego zadania dostarczyć miano m.in. 10 aut, 40 koni, ale i ubiegano się o pożyczkę od rządu w wysokości $10 \mathrm{mln}$ mkp. Środki te miano przeznaczyć na zakup samochodów ciężarowych i ,auto-kolumny asenizacyjnej”"

72 Trudno ocenić liczbę bezrobotnych w mieście, ogólnie w całym kraju było ich w tym czasie 108 377. Dane te przytoczono za Rocznikiem statystycznym Rzeczypospolitej Polskiej z 1927 r., s. 89.

${ }^{73}$ LCVA, sygn. 64/24/111, k. 36.

${ }^{74}$ LCVA, sygn. 64/24/47, k. 1.

${ }^{75}$ LCVA, sygn. 64/19/20, k. 46, 51. W skład komisji weszli m.in. szef wydziału zdrowia Departamentu Spraw Wewnętrznych Litwy Środkowej dr Kozłowski, szef sanitarny 
Trudno jednak stwierdzić, czy doszło do poprawy stanu, ocenić efekty ewentualnych działań. $Z$ dokumentacji magistratu wynika natomiast, że pewne siedziby przeznaczone dla bezdomnych, chorych, odnotowane jeszcze w 1919 i 1920 r., ulegały likwidacji bądź też poszukiwano dla nich innej lokalizacji. Dlatego też pojawiały się nowe adresy placówek, które wymagały doinwestowania, poprawy np. ogrzewania, zainstalowania odwszalni czy kabiny dezynfekcyjnej. Mieściły się one, jak już wspomniano, w różnych lokalizacjach, przy kościołach, domach zakonnych ${ }^{76}$. Zmiany te mogły wynikać też z przeprowadzanych przez magistrat kontroli, oceny stanu użyteczności, w tym i ich zasobu inwentarza. Zachowały się bowiem w dokumentacji magistratu Wilna wykazy sprzętów, np. przytułku nr 1 i 2, z maja 1922 r. Wtedy też zapewne starano się je zewidencjonować, poznać stan wyposażenia ${ }^{77}$. We wspomnianym przytułku nr 2 wykazywano np. 86 łóżek, 23 miski emaliowane, 11 talerzy, 7 kubków, 166 kołder, w tym 18, jak zaznaczono „starych”, 166 prześcieradeł, 105 powłoczek $^{78}$. Przeciętnie zatem dysponowano jedną zmianą bielizny ${ }^{79}$. Trudno jednak określić ten stan jako zadowalający. Mimo problemów organizowano także placówki dla repatriantów ${ }^{80}$. Powstawały one głównie w zachowanych, prywatnych posesjach. Nasilenie ich tworzenia przypada na połowę lat 20. XX w. Jednym $\mathrm{z}$ adresów tych miejsc była ul. Trocka $14^{81}$, gdzie w połowie lat 20. znajdowało się 56 osób w różnym wieku (18-60 lat), o różnej profesji czy wykształceniu, na ogół jednak bez stałej pracy. Najczęściej przebywali tam całymi rodzinami. Trafiali tam nierzadko z miejsca schyłki, np. z odległego Orska w południowej części Uralu, Irkucka na Syberii, ale i Kurska czy z guberni homelskiej ${ }^{82}$. Dozorcą

grupy wojsk Litwy Środkowej ppłk. Maleszewski, referent higieny grupy płk Kiersnowski, naczelny lekarz garnizonu m. Wilna ppłk Wayczyński oraz lekarz m. Wilna Michał Minkiewicz.

${ }^{76}$ LCVA, sygn. 64/24/38, k. 87.

77 LCVA, sygn. 64/24/111 (brak pag.).

78 Tamże.

79 Tamże.

80 Oblicza się, że na tereny ziem polskich do początków 1924 r. przybyła następująca liczba ludności: w roku 1918 - 82 952; w 1919 - 286 350; 1920 - 86 037; 1921 - 482 320; 1922 - 278 750; 1923 - 34 574; 1924 - 13 740. Zatem najwięcej repatriantów na ziemie polskie przybyło w 1919 r., następnie po nawale sowieckiej - w roku 1921. Po tym czasie liczba ta stopniowo malała. Rocznik statystyki Rzeczypospolitej Polskiej, R. 5, 1927, Warszawa 1927, s. 204.

${ }^{81}$ W latach 1905-1907 pod tym numerem czynna była miejska ochronka dla dzieci. Adres ten znany był z działalności Józefa Montwiłła, o czym już wspomniano. R. Jurkowski, dz. cyt., s. 35. N.R, Józef Montwitt, „Tygodnik Wileński”, 13.02.1911, r. 1, nr 7, s. 4.

${ }^{82}$ LCVA, sygn. 64/24/153 (brak pag.). 
posesji przy Trockiej 14 był Jan Niedzwiecki, udostępniający lokale bezpłatnie. Czas pobytu w pomieszczeniach tej posesji przedłużał się nawet do roku. Innym miejscem - „mieszkań na tzw. etapie” - była Franiszkańska 7. Schronienia przy Franiszkańskiej udostępniano za pośrednictwem Wydziału Opieki magistratu. Jednak obowiązywała tu odpłatność za komorne. Trudno jednak opisać wygląd i wielkość tych pomieszczeń. Z relacji jednak wynikać może, że sprowadzało się ono często do zasiedlenia łóżka, chociaż nie zawsze wyłącznie przeznaczonego dla jednej tylko osoby. Uciekinierka z Rosji, ulokowana w sali inteligenckiej na tzw. etapie, przedstawiła sytuację z pierwszych dni stycznia 1925 r. : „(...) mąż z czerwonką a sąsiadka najbliższa na łóżku «chora na piersi» $\mathbf{i}$ «wrzody», brudna ma pełno robactwa, w ubraniu muszę z nią spać, ciągle już od roku" ${ }^{83}$. W dokumentacji magistratu, z tamtego czasu zachowały się też opisy innych osób - repatriantów przebywających w tych pomieszczeniach, na „etapie”, po części utrzymywanych już od 1923 r., w myśl ustawy z 16 sierpnia tego roku o opiece społecznej, przez Wydział Dobroczynności magistratu ${ }^{84}$. Wśród wymienionych lokatorów tych miejsc odnotowano też Leona Kozdela - lat 23, z zawodu jakoby aptekarza, aczkolwiek jeszcze ucznia, który powrócił ze wspomnianego Orska w roku 1923, a po złamaniu ręki zatrudniany był w Wilnie tylko dorywczo jako robotnik. Ponadto przebywała tam Anna Janicka, lat 35, która w roku 1915 wyjechała z Melitopola (w południowej części Ukrainy) do Rosji (?), a po śmierci męża (młynarza) z końcem roku 1922 r. przeniosła się do Wilna, gdzie znalazła miejsce $w$ domu repatriantów, dorywczo pracując m.in. jako praczka bielizny. Utrzymywała 7-letnie dziecko, uczęszczające do szkoły. Kolejnym odnotowanym pensjonariuszem był Kazimierz Jankowski, lat 45, urodzony w Moskwie, gdzie pracował na kolei, powrócił, jak zaznaczył, aby „kształcić dzieci w duchu polskim”. Miał żonę, która nie pracowała, i dwie córki: 5- i 8-letnią. Jednak z powodu trudnej sytuacji materialnej nie był $\mathrm{w}$ stanie zapewnić im pobytu w ochronce (przedszkolu) i nauki w szkole ${ }^{85}$. Władze starały się ratować ogólną sytuację finansową placówek i podopiecznych, często kosztem zatrud-

\footnotetext{
${ }^{83}$ Relacja z 8.01.1925 r., LCVA, sygn. 64/24/153 (brak pag.).

${ }^{84}$ LCVA, sygn. 64/24/155 (informacja z lipca 1924 r.). Jednocześnie stwierdzono, że „prawo do opieki mają osoby przez rok przebywające w gminie w tym: kobiety, dzieci do lat 16 - «ślubne»". Ponadto dzieci pozbawione, rozdzielone od rodziców, także nieślubne, ale przebywające $\mathrm{w}$ gminie, gdzie mieszkała matka. Utrata uprawnień $\mathrm{z}$ tego tytułu następowała po roku nieobecności w gminie, za wyjątkiem odbywania służby wojskowej. Tamże.
}

${ }^{85}$ LCVA, sygn. 64/24/153 (brak pag.). 
nionego tam personelu, zmniejszając obsady ${ }^{86}$, obniżając do minimum często wręcz głodowe racje żywnościowe dla przebywających, o czym już wspominano. Bywało też, że produkty dla placówek opiekuńczych, zapewne z powodu skąpych zapasów, a i tzw. konkurencji wszystkich potrzebujących, przyznawano czasem dopiero po interwencji nawet u samego prezydenta Wilna (Witolda A. Bańkowskiego). Przykładem jest jedno z zażaleń, z 1921 r., gminy żydowskiej skierowane do prezydenta w sprawie odmowy wydania instytucjom żydowskim przypadającej im z mąki żytniej odpowiedniej ilości chleba ${ }^{87}$. Zapewne w wyniku podobnych sytuacji, które miały miejsce, nastąpił podział osób - podopiecznych według wyznania i realizowanych dla nich świadczeń socjalnych. Bezrobotnym chrześcijanom udzielał pomocy bezpośrednio wileński magistrat, a Żydom - gmina, która od magistratu uzyskiwała 56\% sum wydawanych przez Wydział Opieki Społecznej dla chrześcijańskich bezrobotnych ${ }^{88}$. Uruchomiono też kuchnie dla biednych Żydów, jak zaznaczono - inteligentów. Rozchód wydatków na ten cel za lipiec 1927 r. wyniósł 12320 zł, a przeciętnie dziennie w tym miesiącu wydawano ok. 1400 posiłków ${ }^{89}$. Przy czym koszty utrzymania można określić jako stosunkowo wysokie, gdyż ceny produktów w mieście, w porównaniu do innych miast ziem polskich, były tu wyższe. Dla porównania warto przytoczyć ceny z roku 1925 i 1926. I tak, cena kg chleba wynosiła w Wilnie 53 gr, w Warszawie 50 gr, kg mąki pszennej 100 gr, w Warszawie 60 gr, kg słoniny - 289 gr, w Warszawie - 244 gr. Cena masła za kg kształtowała się w Wilnie na poziomie 590 gr, a w Warszawie - 504 gr. Tańsza była wołowina: w Wilnie za kilogram kosztowała 150 gr, w Warszawie 202 gr $^{90}$. Cena mydła w Wilnie w 1926 r. wynosiła $161 \mathrm{gr} \mathrm{za} \mathrm{kg}^{91}$. Zatem utrzymanie pensjonariuszy w tej placówce, jak i w innych instytucjach o podobnym profilu, nastręczało sporo trudności. Na przedmieściach Wilna w Pospieszce w końcu sierpnia $1926 \mathrm{r}$. dla przeszło 100 żydowskich dzieci szkolnych uruchomiono kolonie. W ich otwarciu uczestniczyły władze miejskie, a koszty utrzymania na wstępie oceniano na kwotę 30 tys. zł. Liczono przy tym na wsparcie Amerykańskiej Komisji Pomocy Żydom - TOZ ${ }^{92}$. Kolonie miały trwać

${ }^{86}$ LCVA, sygn. $64 / 19 / 22$, k. 4 . W tej spawie odnotowano np. zabranie rzeczy po zmarłej Annie Gimpel przez siostrzenicę Aleksandrę Szeplow.

${ }^{87}$ LCVA, sygn. 64/24/108 (brak pag.).

${ }_{88}$ Tamże. LCVA, sygn. 64/24/299, k. 6.

${ }^{89}$ Tamże.

${ }^{90}$ Rocznik statystyki Rzeczypospolitej Polskiej, 1927, R. 5, Warszawa 1927, s. 335, 340.

91 Tamże, s. 335.

${ }^{92}$ LCVA, sygn. 64/24/299, k. 22. TOZ - Towarzystwo Ochrony Zdrowia Ludności Żydowskiej - organizacja powstała w 1921 r. Wywodziła się z rosyjskiej organizacji OZE. 
przez trzy miesiące, organizowane w trzech grupach, dla łącznej liczby przeszło 300 dzieci. Dla żydowskich dzieci ze szkół powszechnych planowano także zorganizowanie latem 1927 r., przy pomocy magistratu, półkolonii letnich. Wystąpiono do zarządu miasta o kwotę 5600 zł na ten cel. Półkolonie miały być uruchomione w trzech różnych miejscach Wilna, m.in. na Nowym Mieście i przy ul. Beliny $5^{93}$. Z pomocą TOZ urządzono też przy poradni (Stacji Ochrony Zdrowia) na ul. Pohulanki (2) kuchnię mleczną dla matek i ich dzieci ${ }^{94}$.

Od października 1927 r. obowiązywał wprowadzony przez magistrat 10 gr dodatek do ceny każdego „kilowatu zużytej elektryczności”, który miał być przeznaczony na rzecz bezrobotnej ludności ${ }^{95}$. Pojawia się także informacja o istnieniu przy Połockiej 4 Domu noclegowego dla mężczyzn. Obowiązywała jednak opłata za nocleg, która wynosiła 5 gr od osoby, a chętnych przyjmowano do godziny 22, ale z koniecznością opuszczenia domu po godz. 6 rano. W ramach ceny za nocleg przewidywano możliwość skorzystania $\mathrm{z}$ kąpieli ${ }^{96}$. Opracowywano regulaminy obowiązujące chorych, zapewniające zaprowadzenie pewnej dyscypliny w placówkach, starając się egzekwować ich przestrzeganie. W myśl regulaminu przewidzianego dla chorych w szpitalu zakaźnym nakazywano: „(...) wszyscy, za wyjątkiem obłożnie chorych wstawać o 7, posłać łóżka, umyć się, przy ogólnym stole spożywać posiłki, o 9 (21) cisza, dbać o porządek (...) nie wolno prać w łazience bielizny (...)"97.

Rozszerzano profil usług opiekuńczo-medycznych czy też reaktywowano placówki czynne jeszcze przed czasem wojennym. Działania te ukierunkowane były nadal na zapobieganie chorobom zakaźnym i społecznym, w tym zwalczanie gruźlicy, zapewnienie opieki biednym i bezdomnym. Otwarto m.in. z inicjatywy Zarządu Wileńskiego Stowarzyszenia Ochrony Zdrowia Ludności Żydowskiej poradnię przeciwgruźliczą, w której pracowała m.in. dr H. Uciechowska. Podawano zagrożonym tran, zastrzyki z tuberkuliny, kontrolowano stan dzieci.

Koncentrowano się na zapobieganiu chorób, głownie oczu (jaglicy), skóry, gruźlicy. Ukierunkowana była na opiekę na dziećmi. Jedną z form było finansowanie akcji kolonii letnich. Tamże; N. Aleksiun, Towarzystwo Ochrony Zdrowia Ludności Żydowskiej w Polsce (TOZ). (Polin), https://sztetl.org.pl/pl/slownik/towarzystwo-ochrony-zdrowialudnosci-zydowskiej-w-polsce-toz [dostęp: 20.01.2020].

${ }_{93}$ LCVA, sygn. 64/24/299, k. 2.

${ }^{94}$ LCVA, sygn. 64/19/38, dane z 25 X 1925 r. (brak pag.).

${ }_{95}$ LCVA, sygn. 64/24/299, k. 8.

${ }^{96}$ Wiadomość o Domu noclegowym odnotowano jednak dopiero z początkiem $1928 \mathrm{r}$. Placówka ta funkcjonowała do 1939 r. LCVA, sygn. 64/24/305 (brak pag.). P. Krasnopolski (red.), Wilno i województwo Wileńskie. Informator i Księga adresowa na rok 1939, R. III, Wilno 1939, s. 20.

${ }^{97}$ LCVA, sygn. 64/19/348, k. 401. 
Czynne było także sanatroium dla małych pensjonariuszy przy ul. Letniej 3, przewidziane na 30 łóżek. W prowadzeniu tych instytucji korzystano ze wsparcia Rady miejskiej, do której zwracano się o subsydia $^{98}$.

\section{Próba podsumowania}

Liczba instytucji dobroczynnych, a i w pewnym stopniu leczniczych, wykazywanych od 1919 r. jako czynnych, do 1927 r. wydaje się nie ulegać większym zmianom. Aczkolwiek od tego roku rozpoczął się okres poprawy koniunktury gospodarczej kraju ${ }^{99}$, co mogło mieć też wpływ na późniejszy stan ich funkcjonowania. Zdołano utrzymać przez ten okres niektóre siedziby instytucji dobroczynnych, np. mieszczące się przy ul. Rossa czy Połockiej. Niemniej czas ich działalności, a bywało, że i przeznaczenie - jeszcze do połowy lat 20. - ograniczano, co wynikało zapewne z potrzeb i możliwości aprowizacyjnych. Wymaga to jednak dalszych poszukiwań źródłowych i analizy ${ }^{100}$. Bowiem według danych magistratu $\mathrm{z}$ roku 1924 obliczano, że funkcjonowało 47 instytucji przeznaczonych dla dzieci oraz 8 dla starców i kalek (zarówno kobiet, jak i mężczyzn). Wskazywano też na dwa domy noclego$w^{101}$. Niemniej jednak trudno tylko na tej podstawie wyrokować co do ciągłości w użyteczności i kontynuowania działalności. W prowadzeniu tych instytucji przeważały organizacje społeczne i świeckie. Jeśli chodzi o np. dziecięce: w 36 przypadkach znajdowały się w zarządzie własnym. W sześciu zaś - we władaniu duchowieństwa. Wymieniano też zakłady fundacyjne: $w$ jednym przypadku określane jako świeckie i kolejne prowadzone przez duchownych. Trzy zakłady określono jako zakłady państwowe i to $\mathrm{w}$ zarządzie własnym i społecznym ${ }^{102}$. Prowadzone były także instytucje odrębne dla poszczególnych narodowości, np. białoruskiej. Stan higieniczny wielu tych miejsc, w tym samego miasta, oceniano jednak jeszcze jako niezadowalający, a nawet zły. $\mathrm{Na}$ posiedzeniach służb sanitarnych starano się aktywizować, pobudzać efektywność funkcjonowania personelu, w tym sześciu działających wtedy w mieście lekarzy sanitarnych, których liczbę, w porównaniu do roku 1919, jednak ograniczono ${ }^{103}$. Pozostałemu personelowi, w tym

\footnotetext{
${ }_{98}$ LCVA, sygn. 64/24/299, s. 23.

99 A. Jezierski, C. Leszczyńska, dz. cyt., s. 266.

${ }^{100}$ Pewnym problem są $\mathrm{w}$ tym względzie zmiany nazwy placówki przy utrzymaniu jej przeznaczenia.

${ }^{101}$ LCVA, sygn. 64/24/156, k. 26.

102 Tamże.

${ }^{103}$ Protokół z 5 IX 1927 r., LCVA, sygn. 64/19/157, k. 438.
} 
pielęgniarskiemu, często nie dość wyraźnie określano kompetencje i zakres działalności. Nie odnotowano też w wielu miejscach liczby podopiecznych, jak i osób zabezpieczających opiekę. W tym brak danych personalnych tych osób. Pamiętać jednak należy też, że w pracy placówek mogły to być siły „przygodne”, angażowane na pewien czas czy nawet podejmujące tam służbę spontanicznie i z to różnych powodów. Zatem w wielu przypadkach nie były to osoby przygotowane do sprawowania zadań opiekuńczych. Pamiętać bowiem trzeba, że szkolnictwo pielęgniarskie $\mathrm{w}$ kraju znajdowało się dopiero $\mathrm{w}$ fazie organizacji i nie zapewniało jeszcze dopływu kadr do tej działalności. W tej sytuacji zdarzały się wypadki nagannych zachowań personelu w stosunku do podopiecznych. Starano się jednak sprawdzać tego typu okoliczności, wyciągając konsekwencje wobec winnych. Istniał zatem, co należy podkreślić, pewien system kontroli tej służby, sprawowany przez Wydział Opieki urzędu miasta, co prawda doraźnie. Dodać warto, że funkcjonowały, i to w miarę bez większych problemów, struktury placówek leczniczych, w tym głównie szpitali. Pewne niedomagania, zwłaszcza służb socjalnych domów opieki, wynikały w dużym stopniu z trudnej sytuacji, czasu niepokojów, a przede wszystkim kłopotów finansowych, w tym związanych z aprowizacją, nie tylko żywności. Po 1927 r., jak wskazuje dokumentacja i na co już zwracano uwagę, następowała stopniowa poprawa sytuacji.

Warto jednak dodać, że na przestrzeni 18 lat (1919-1927), zmagając się z różnymi problemami, kształtowała się w tym mieście polityka społeczna. Porządkowano i formowano struktury pomocowe służące potrzebującym, mimo że odbywało się to często w nagły sposób, w drodze decyzji służb odpowiedzialnych za ten dział. Niwelowano też ,ad hoc", w pośpiechu niedostatki, braki mające niekorzystny wpływ na życie i zdrowie samych mieszkańców czy uciekinierów ze Wschodu.

\section{Bibliografia}

\section{Źródła aktowe:}

Lietvas centrinis valstybes archywas, w Wilnie (LCVA)

Akta magistratu Wilna:

LCVA, sygn.6/24/6; 6/29/8; 64/19/14;64/19/20;64/19/22; 64/19/34; $64 / 19 / 37 ; 69 / 19 / 38 ; 64 / 19 / 57 ; 64 / 19 / 70 ; 64 / 19 / 157 ; 64 / 19 / 313$; $64 / 19 / 348 ; 64 / 24 / 2 ; 64 / 24 / 15 ; 64 / 24 / 38 ; 64 / 24 / 47 ; 64 / 24 / 48 ; 64 / 24 / 65$; $64 / 24 / 82 ; 64 / 24 / 108 ; 64 / 24 / 111 ; 64 / 24 / 132 ; 64 / 24 / 152 ; 64 / 24 / 153$; 64/24/155; 64/24/156; 64/19/157; 64/24/299; 64/24/305; 55/8/1167. 


\section{Źródła drukowane:}

Kalendarz ilustrowany „Kurjera Litewskiego” na rok 1909.

Kieziewicz D., Zdrowotność i lecznictwo w pótnocno-wschodnich województwach Rzeczypospolitej Polskiej, „Nowiny społeczno-lekarskie" 1929, nr 1.

Kłos J., Wilno, Przewodnik Krajoznawczy, Wilno 1937.

Księga adresowa miasta Wilna, Wileński Kalendarz informacyjny na rok 1933, Wilno 1933.

Księga adresowa miasta Wilna 1935, Wileński Kalendarz Informacyjny, R. 30, Wilno 1935.

Rocznik statystyczny Rzeczypospolitej Polskiej, R. 5, 1927, Warszawa 1927.

„Tygodnik Wileński”, 13.02.1911, nr 26.

\section{Opracowania:}

Dziobek-Romański J., Samorzad terytorialny w II Rzeczypospolitej w pierwszych latach po odzyskaniu niepodległości, [w:] Historia magistra vitae. Księga jubileuszowa, Lublin 2007.

Felchner A., Rodzina w II Rzeczypospolitej - jej główne zagrożenia $z e$ strony chorób, „Medycyna Nowożytna. Studia nad Kulturą Medyczną" 2019, t. 25, z. 1.

Jezierski A., Leszczyńska C., Historia gospodarcza Polski, Warszawa 2003.

Jurkowski R., Wileńskie instytucje i towarzystwa dobroczynne w latach 1905-1907 w świetle doniesień „Kuriera Litewskiego” $i$ „Dziennika Wileńskiego”, cz. 1, „Przegląd Wschodnioeuropejski” 2016, nr 7/1.

Kozyra W., Polityka administracyjna władz polskich na Ziemiach Wschodnich Rzeczypospolitej polskiej w latach 1918-1926, „Annales Universitates Mariae Curie-Skłodowska” 2005, t. LIX.

Majer P., Struktura, zadania i prawne podstawy działalności aparatu państwowego II RP do spraw reparacji, reemigracji i emigracji, „Studia Prawnoustrojowe” 2015, nr 27.

Musiał W., Modernizacja Polski. Polityki rzadowe w latach 1918-2004, Toruń 2013.

Samsel A., Rodziny potrzebujace wsparcia w II Rzeczypospolitej jakość życia, realizacja podstawowych funkcji, opieka społeczna, „Wychowanie w Rodzinie” 2013, t. VII/, nr 1.

Stawicki R., Samorzad terytorialny w II Rzeczypospolitej. Zarys prawno-historyczny, Warszawa 2015.

Wnęk J., Pandemia grypy hiszpanki (1918-1919) w świetle polskiej prasy, „Archiwum Historii i Filozofii Medycyny” 2014, t. 77. 


\section{Źródła internetowe:}

Aleksiun N., Towarzystwo Ochrony Zdrowia Ludności Żydowskiej $w$ Polsce (TOZ). (Polin), https://sztetl.org.pl/pl/slownik/towarzystwo-ochrony-zdrowia-ludnosci-zydowskiej-w-polsce-toz.

Encyklopedia PWN, hasło Wilno, https:/encyklopedia.pwn.pl/haslo/ Wilno;3996406.html.

Gawryszewski A., Ludność Polski w XX wieku, Warszawa 2005, http:// rcin.org.pl/Content/2425/WA51_13508_r2005-nr5_Monografie.pdf.

Kuzak R., Grypa hiszpanka w Polsce 1918-1920. Liczba ofiar i prawdziwy obraz epidemii, https://wielkahistoria.pl/grypa-hiszpankaw-polsce-1918-1920-liczba-ofiar-i-prawdziwy-obraz-epidemii/.

Konwent Polonia - Archiwum Korporacyjne, http://www.archiwumkorporacyjne.pl/index.php/muzeum-korporacyjne/wilno/. 